\title{
Parties in Congress
}

The Democrats are the party of government activism, the party that says government can make you richer, smarter, taller, and get the chickweed out of your lawn. Republicans are the party that says government doesn't work, and then get elected and prove it. (P. J. O'Rourke)

One of the most often overlooked aspects of Congress is the role played by political parties. It is true that parties in the United States are weaker and more fragmented than many of their Western European counterparts. It is also true that the majority of members of Congress cannot rely on their party label alone to assure their election and instead must develop their own platform and reputation. However, it is a fact that since 1945 only a handful of candidates for Congress have successfully gained election without the official endorsement of one of the two major parties. Consequently, parties are still of vital importance in Congress and deserve fuller understanding.

\section{Organisation by party}

On 24 May 2001, Senator Jim Jeffords of Vermont, in a statement he called his 'declaration of independence', 
announced that 'In order to best represent my state of Vermont, my own conscience, and the principles I have stood for my whole life, I leave the Republican Party and become an Independent'. Jeffords was not the first sitting member of Congress to defect from the party under whose banner they were elected. Indeed, since 1981 there have been sixteen party defections in Congress, although, before Jeffords, only one from the Republican Party in that time. What made Jefford's decision so notable, was that his actions changed the balance of power in the Senate. The results of the 2000 election had left the Senate divided between fifty Democrats and fifty Republicans. Jefford's defection, placed the Senate in the hands of the Democrats.

Congress is organised along party lines. The leaders of the Democrat and Republican Parties in the House of Representatives and Senate hold key positions in their chamber with power over the legislative agenda, the organisation of Congress and matters such as members' committee assignments. The largest share of this power is reserved for the leadership of the majority party. The main leadership posts are outlined in Box 5.1 and their roles are outlined below.

\section{Party leaders in the House of Representatives}

\section{Speaker of the House}

Party politics aside, the Speaker is an extremely important figure in the Government of the United States, being second only to the Vice-President in the line of succession to the presidency. Within the House itself the Speaker is the presiding officer, referring bills to committees, presiding over debates and judging points of order. These roles occasionally afford the Speaker a great deal of influence over the fate of legisla- 


\section{Box 5.1 Party leadership in the 107th Congress \\ Majority party \\ Minority party}

House of Representatives

\section{Republicans}

Speaker of the House:

Dennis Hastert

Majority Leader:

Richard Armey

Majority Whip: Tom Delay

Republican Conference Chair:

J. C. Watts

Republican Policy Committee

Chair: Chris Cox

\section{Democrats}

No equivalent post for the minority party

Minority Leader:

Richard Gephardt

Minority Whip: Nancy Pelosi

House Democratic Caucus

Chair: Martin Frost

Democratic Policy Committee

Vice-Chairs: Several

\section{Senate}

\section{Democrats}

Majority Leader: Tom Daschle Assistant Majority Leader

(Democrat Whip):

Harry Reid

Democrat Policy Committee

Chair: Byron Dorgan

No Democrat equivalent

\section{Republicans}

Minority Leader: Trent Lott Assistant Minority Leader

(Republican Whip):

Don Nickles

Republican Policy Committee

Chair: Larry Craig

Republican Conference Chair:

Rick Santorum

tion, but in reality, for most of the time, such duties are formalities and as such are carried out by assistants. The power of the modern Speaker is derived partly from the institutional position and duties and partly from his other role, that of leader of the majority party in the House. In this role the Speaker has a great deal of influence over the pursuit of his party's legislative agenda. $\mathrm{He}$ is a central figure in deciding 
legislative priorities, determining committee assignments, accommodating members' requests and, through the Rules Committee (discussed below) the agenda of the House as a whole. He will act as the party's spokesman and chief negotiator with the minority party leaders, the Senate and the President. While any leader of the party has few official sanctions to bring rogue members into line, the importance of the post of Speaker and his central position in the party's 'communication network' gives the office holder a great deal of influence to dispense favours and persuade members with the aim of forming the coalitions necessary to get legislation passed.

Ultimately, the power of the Speaker will depend on the ability of the office holder. Over the years, some speakers have used the tools at their disposal to great effect. Legendary speakers in the history of the House include 'uncle' Joe Cannon (speaker, 1903-11) and Sam Rayburn (1940-47, 1949-53, 1955-63) who were noted for the power with which they brought to the post of Speaker. As discussed in chapter 4, Newt Gingrich (1995-99) attempted to use his position within the Republican Party and Congress as a whole to concentrate power of the legislative agenda in the Speaker's chair. How far he succeeded will be discussed below.

\section{Majority Leader}

The Majority Leader acts as deputy to the Speaker. His role, however, is more 'hands-on' than the Speaker. The Majority Leader is in charge of guiding legislation through the floor debates, negotiating with minority party members and building coalitions to pass the majority party's legislative priorities. 


\section{Minority Leader}

There is no minority party equivalent to the Speaker of the House. Instead, the Minority Leader must play the leadership roles of both the Speaker and Majority Leader within his own party. The Minority Leader plays a central role in setting the minority's legislative priorities, negotiating with the majority and with the White House, assigning members to committees and building coalitions to pass or defeat legislation on the floor.

\section{Majority Whip}

The Majority Whip has the job of marshalling the rank and file of the majority party. He acts as a link between the leaders and party members in Congress, gathering information on members' voting intentions, persuading members to follow the party line and providing information about forthcoming votes and the leadership's legislative priorities.

\section{Minority Whip}

The Minority Whip performs the same functions for the minority as the Majority Whip does for the majority.

\section{Republican Conference Chair}

The Republican Conference contains all Republican members in the House who then elect the chair. The chair acts as a spokesman for the party, a mediator between Republicans where there are sharp policy disagreements, and as a disciplinarian of members who consistently defy the party line. The conference as a whole is also the arena where leadership elections take place and where disputes over internal Republican matters are finally settled. 


\section{Democratic Caucus Chair}

The Democratic Caucus and its chair perform the same role for the Democrats as the Conference does for the Republicans.

\section{Republican Policy Committee Chair}

The Republican Policy Committee has the job of analysing legislative proposals and recommending strategy to the party. It also produces briefing papers to help members in answering questions from the public and the press.

\section{Democratic Policy Committee Vice-Chairs}

The Democratic Policy Committee and its vice-chairs perform the same role as the Republican Policy Committee.

\section{Party leaders in the Senate}

Senate Majority Leader

The leader and main spokesman of the majority party in the Senate. The Majority Leader manages the day-to-day business on the Senate floor, working with committee leaders, scheduling floor debates and setting legislative priorities.

\section{Senate Assistant Majority Leader}

The Assistant Majority Leader performs a similar function to the Majority Whip in the House. The job entails keeping party members informed of upcoming issues and working to build coalitions to ensure that the legislation supported by the party pass on the floor of the Senate.

\section{Senate Minority Leader}

The Senate Minority Leader is the head of the minority party and fulfils the equivalent role of the Senate Majority Leader. 
Senate Minority Whip

The Senate Minority Whip is the minority party equivalent to the Assistant Majority Leader.

\section{Senate Republican Conference}

The Senate Republican Conference is the meeting of all Republican Senators and acts as a forum where party leaders and rank-and-file members can meet and discuss their concerns.

\section{Senate Republican Policy Committee}

The Committee and its chair is charged with developing policy and legislative strategy.

\section{Senate Democratic Conference Secretary}

The third-ranking Democrat Senator, the Democratic Conference Secretary oversees the Conference which performs the equivalent role for Democrats as the Republican Conference.

\section{Senate Democratic Policy Committee}

The Senate Democratic Policy Committee performs the equivalent role to the Republican Policy Committee.

\section{The power of party leaders}

A common caricature of parties in the United States is of loose organisations with little ability to control or even choose the elected officials who represent them. To a certain extent this is true; as was discussed in chapter 2, the diversity of the nation and the primary election system has led to members of Congress having a great deal of autonomy from their party. However, leaders attempt to use the limited powers at their disposal to keep the party in line. 


\section{Leadership styles}

The 'power to persuade' is normally associated with the President, but it is no less important to party leaders in Congress. With few official sanctions available to discipline members, the success of a leader in controlling the party often depends on their personal diplomatic skills. Cajoling, persuading and negotiating with members in order to form voting coalitions is an essential part of a leader's job. Different leaders have used different approaches to achieve this end, with varying results.

One of the most successful leaders in this way was Lyndon B. Johnson, Senate Majority Leader from 1955 to 1960. Johnson used his intellect, presence and sheer physical size to persuade or even bully Senators into supporting the party's position. This became known as 'the treatment' and was described by Rowland Evans and Robert Novak thus:

The tone was supplication, accusation, cajolery, exuberance, scorn, tears, complaint, the hint of threat. It was all these together. It ran the gamut of human emotions. Its velocity was breathtaking, and it was all in one direction. Interjections from the target were rare. Johnson anticipated them before they could be spoken. He moved in close, his face a scant millimetre from his target, his eyes widening and narrowing, his eyebrows rising and falling. From his pockets poured clippings, memos, statistics. Mimicry, humour, and the genius of analogy made The Treatment an almost hypnotic experience and rendered the target stunned and helpless ... ${ }^{1}$

As Evans and Novak suggest, LBJ's success was not simply due to intimidation. Party leaders hold advantage over other members of their party due to their knowledge of the issues and Congressional procedures. This is partly accrued through 
the length of service in Congress which leaders inevitably have, but also through the party's communication network. Leaders need to keep their finger on the pulse of the whole range of legislative activity within their domain.

Bob Dole, Senate Majority Leader 1985-87 and 1995-96, and Minority Leader 1987-95, was more of a coalition builder than LBJ, but like Johnson he also relied on an encyclopaedic knowledge of the legislative process. Senator Mark Hatfield, who worked closely with Dole, described his leadership style thus:

First of all, he is an information gatherer. In other words, he has to know where different members of the Senate are coming from ... maybe he has enough Republican votes to pass something. But if he doesn't . . . then he has to move across the aisle, and find out who on that side of the aisle he can bring together with those Republicans to pass a bill. Now that's the role of the majority leader. His style is different than LBJ . . . Senator Dole gathers information . . . I'm not aware that Senator Dole ever threatened ... And I'm not sure that I have ever heard any one of my colleagues say he'd threatened them ... Senator Dole is not that type of leader. He's a consensus builder. ${ }^{2}$

Newt Gingrich, House Speaker 1995-98, had a contrasting style to Dole's. Gingrich was more aggressive and partisan. He came to the job on the back of a Republican electoral landslide, and was determined to push through the Contract with America. Gingrich personalised the Republican program and the inevitable conflict with the Clinton White House more than any other Speaker. He attempted to centralise power in the Speaker's chair by pushing through changes in the rules of Congress which diminished the autonomy of committees (discussed in chapter 4). With the support of newly elected 
Republican members (many of whom initially felt loyalty towards Gingrich for his part in their election), Gingrich persuaded the party to vote to award the chair of three committees to members more sympathetic to his views, passing over the norm of seniority.

\section{Control of the legislative process}

As the example of Gingrich suggests, party leaders have more tools at their disposal than simply force of personality. The Constitution states that 'Each House may determine the rules of its proceedings' (Article 1, Section 5); at the start of each Congress, the majority party leaders can propose changes to the way either the House or Senate operated, provided the changes are approved by a majority of Senators or Representatives. In this way, Gingrich instituted changes in the committee system, much as Democrats did in the 1970s. Alternatively, leaders are in an advantageous position to push through changes within their own party which affect their degree of control over the legislative process, as Gingrich did by ensuring committee chairs were inhabited by members who would be sympathetic to his agenda. The leadership also has some influence over who is assigned to which commitee.

The leader of the majority party in the House or Senate also have the power of referral. When a bill is introduced it must be referred to a committee for consideration. While this procedure is usually straightforward, there are occasions when it can give the leadership influence. During the 1960s, the Democrat leadership was trying to push civil rights legislation through Congress, but was being thwarted by committee chairmen opposed to the measures. In an attempt to overcome this opposition, the leaderships in House and Senate pursued 
different strategies regarding committee referral. In the House, the bill was written as to allow the leadership to refer it to the Judiciary Committee, a strategy which increased its chances of success as the committee was chaired by Emanuel Celler, a supporter of civil rights. The Senate leadership was aware that the Judiciary Committee of the Senate was dominated by opponents of civil rights who would kill the bill. Consequently, the leadership delayed any action until the measure had passed the House, which allowed them to take the rare step of not referring the bill to a committee at all. After a vote on the floor, the Senate agreed to consider the House bill without any committee consideration. It was this tactic which facilitated the passage of the groundbreaking Civil Rights Act of 1964.

Since 1974, the Speaker of the House of Representatives has also had the option of multiple referral. If the Speaker feels that a bill deals with issues with fall under the jurisdiction of more than one committee, he can send either all or parts of the bill to those committees. This can affect the chances of the whole bill or parts of it surviving the committee process. With different committees having different overall viewpoints, the ability to refer bills to more than one committee gave the Speaker a greater deal of influence over the legislative process than he had before.

Perhaps the greatest of the party leaders' powers is that of scheduling. The ability to influence which issues rise to the top of the Congressional agenda, and which see no action due to time running out. If a bill does not pass into law by the end of the Congress into which it was introduced, it fails and must be re-introduced from the beginning in the following Congress and begin the process again. With many pieces of legislation competing for space on the agenda, it is an important power to be able to influence which issues take priority. 
How this works in practice differs between the House of Representatives and the Senate.

\section{House Rules Committee}

The House Rules Committee has responsibility for regulating the schedule and debates in the chamber of the House of Representatives. When a committee has completed its work on a bill, it will report the legislation to the Rules Committee for a rule to be issued. The rule sets out the maximum amount of time to be allowed for debate and determines whether amendments are allowed to be offered. Three types of rule exist: an open rule allows amendments to be offered on any part of the bill during the debate, a closed rule forbids any amendments being offered, dictating that the bill can either be passed or failed in its original form but not altered. Alternatively a modified rule allows amendments to be offered on specified parts of the bill, but not on others. Which rule is issued can have a significant effect on the chances of the bill passing into law, or at least, succeeding in its original form.

The power to finally decide when a bill is placed on the Congressional schedule and how the debate will take place is a significant one. Consequently, the rules committee is dominated by the leadership of the two parties. However, as with all issues, power ultimately resides with the House of Representatives as a whole. Rules issued by the committee must be passed by a majority vote in the House to come into effect. In the majority of cases this is a formality, although on occasions can cause controversy. Once the rule has been agreed the bill it is concerned with can then be placed on the House calendar for debate. 


\section{Unanimous consent agreements in the Senate}

The Senate has no rules committee, however the scheduling and structuring of debates is still a matter for party leaders. Instead of issuing rules, as in the House, the leaders of the Democrats and Republicans will craft what are termed as unanimous consent agreements. The agreement will outline when a bill is debated and how long that debate is allowed to continue. It will be put to the Senate and if there is no objection, debate can proceed. The problem with this system is that, as the name suggests, the agreements need unanimous consent and as such can be disrupted by a single Senator. The effects of this will be discussed in the next chapter.

\section{Conference committees}

Even after a bill has been debated and passed, party leaders still have an opportunity to influence its fate. As will be discussed in the next chapter, one of the difficulties of a bicameral system is that the House and Senate may not agree on the details of a particular piece of legislation. Even if the same bill survives the committee stages of the two chambers, different amendments may be offered during floor debate. When this situation occurs, and neither chamber seems willing to accept the other's version as a whole, a House-Senate conference committee will be convened to negotiate the differences and produce a final version of the bill. Consequently, the members who sit on this committee have a considerable amount of influence over the final shape of legislation. Changes introduced in committee or during floor debate may disappear from the legislation at the conference stage. Each time a conference committee is convened, it is the party leadership who proposes the membership from their side of Congress. While it is normal for committee members who have been active in 
the formulation of the bill to be appointed and, ultimately, the full membership House or Senate retains a veto over the appointment process, this procedure can give the party leadership influence over the shape of the final legislation.

\section{Sanctions on maverick members}

Party leaders have few sanctions at their disposal with which to bring members into line. Unlike parties in the United Kingdom, they cannot threaten them with the removal of the party label at the next election or offer promotion to the cabinet. The sanctions available to Congressional party leaders are less formal, and are connected to the influence they have over scheduling, agenda setting, coalition building and committee appointments. By providing the appropriate committee appointment, giving legislation priority on the schedule and using their influence to persuade others to move the legislative process along, leaders can aid members in achieving their goals. Assurances of priority for their wishes can be used to persuade a member to follow the party line on an important vote. Similarly, members who persistently ignore party demands could find the leadership somewhat less than enthusiastic in accommodating their requests.

\section{Party unity}

The lack of sanctions at the leadership's disposal to control maverick members is only part of the reason why unity between party members in Congress is low. In many cases it is not in the interest of the party to demand all members vote the same way. Leaders are aware of the demands which the desire for re-election place on individual members. When considering how they cast their vote or set their priorities, members must give careful consideration to how their actions 
will be received by the voters. They are aware that any one vote cast could be turned into an issue by a future opponent in either the primary or general election. Such constituency pressures can differ greatly between members of the same party. It is in the interest of leaders to help their members in their bid for re-election, and understand that the priorities of the party and those of individual constituencies will sometimes conflict.

\section{Party government}

The system of separation of powers and the weaknesses in party discipline has meant that any form of party government, so common in European legislatures, is extremely difficult to achieve. The Congressional system works on compromise, persuasion and trade-offs. It is near impossible for the majority party in Congress to push through a comprehensive slate of policies. The times in American history where a legislative programme, such as the New Deal in 1934, has succeeded in becoming law, the driving force has been the White House rather than Congressional parties.

When Newt Gingrich became Speaker of the House in 1995 , he made a bold attempt at party government. His strategy was based on two threads: the changes in the committee system designed to give more influence to the Speaker, and the Contract with America. For many House Republicans, especially those who were first elected in 1994, the Contract was seen as having been central to their takeover of Congress and consequently they felt a duty to the voters to ensure the passage of the legislation promised within it. Initially, some members wore laminated copies of the Contract around their necks, others referred to it as their 'bible'. Bolstered by the support of new Republican members who attributed to Gingrich a large 
part in their election, the Speaker attempted to marshal his party to ensure the passage of the party's programme.

This attempt to unify the Republican Party behind a legislative programme was successful to a degree, but its failures highlighted the difficulty in achieving anything approaching party government. The commitment made in the Contract was not to pass the proposals into law, but to bring them to a vote on the floor of the House of Representatives within 100 days. The Republicans, filled with determination following the election, fulfilled this pledge. Furthermore, they also succeeded in passing into law legislation concerning Congressional accountability, unfunded mandates and stockholders rights, the latter being passed despite a presidential veto. However, the majority of their proposals never completed the journey into law. Three pieces of legislation suffered at the hands of a presidential veto, an attempt to give the President powers to veto parts of a bill was struck down by the Supreme Court as unconstitutional and a proposal to limit the number of times a Representative could seek re-election was defeated in the House itself. An important stumbling block, however, was the US Senate. Senate Republicans had not signed the Contract and did not feel bound to supporting all elements in it. The nature of the Senate is less confrontational than the House and as such allows the party leadership less scope in enforcing a party line.

Once the House had dealt with the provisions contained in the Contract, the initial enthusiasm by Republicans for any form of party government subsided. As the time for reelection drew nearer, traditional local political concerns took centre stage. With no publicly issued manifesto to hold members to, the familiar patterns (and difficulties) of party control re-emerged. 


\section{Relations between leaders}

How smoothly Congress functions can be affected by how well the party leaders can get on. Sometimes this can just be a matter of personality. Before the terrorist attacks of 11 September 2001, politics in the House of Representatives were complicated by the strained relationships between the leaders of the Democrats and Republicans, particularly those between Richard Gephardt and Richard Armey. During the 104th Congress, Democrats attempted to make political capital by demonising House Speaker Newt Gingrich. A similar attempt had been made on Senate leader Thomas Daschle by Republicans in the 107th Congress.

It can also be a matter of party differences. Consequently, a change in which party 'controls' the House or Senate can have a significant effect on the politics of the federal government as a whole. If one party controls the House and their opponents control the Senate, in theory it can make agreement more difficult to reach. However, this should not be overstated, as discussed above, the Contract with America ran into problems in the Senate, despite the Republicans holding a majority in both chambers. On the other hand, Congress managed to pass often controversial campaign finance reform in 2002, despite the House being controlled by Republicans and the Senate by the Democrats.

\section{Summary}

While parties in the United States are weaker than their Western European equivalents, they still play a major role in Congress. Which party controls the House or Senate makes a big difference to the politics of Capitol Hill. The party with a majority will dominate the committees and have a major say 
over which issues make it onto the Congressional agenda. The party leaders have the most influence over the legislative process, although they are limited in the formal sanctions they have at their disposal to control their own party members. Consequently, achieving any form of 'party government' can prove difficult.

\section{Notes}

1 R. Evans and R. Novak, Lyndon B. Johnson: The Exercise of Power (The New American Library, Inc., 1966), p. 104.

2 Senator Mark Hatfield, PBS Frontline, 10 July 1996. 